\title{
THE SIGNIFICANCE OF EMOTIONAL INTELLIGENCE AND LEADERSHIP STYLES OF SENIOR LEADERS IN THE SOUTH AFRICAN GOVERNMENT
}

\author{
N. M. G. Mfikwe, * T. G. Pelser**
}

Received: 5. 4.2016

Professional paper

Accepted: 28. 11. 2017

UDC 005.5:165.195>328(680)

\begin{abstract}
A significant body of research over the past two decades found the emotional intelligence abilities to be associated with a range of important work-related behaviours. The aim of this study was to establish the gender differences and significance of emotional intelligence and leadership styles of senior leaders in the South African government. For this purpose, a sample of 85 senior managers were selected from various government departments in South Africa. The results of the study show that emotional intelligence and leadership styles do relate to one another. How-
\end{abstract}

\section{INTRODUCTION}

The presence of women in senior management roles, especially in the South African context, has changed management cultures in most organisations. Leaders in every organisation need high emotional intelligence because they represent the organisation to the public, to those they lead and those they interact with on behalf of the organisation. Most of all, leaders in the ever, there were no significant differences in leadership styles and emotional intelligence between male and female respondents. This is due to the fact that the core management criteria and standards used to evaluate the performance of senior managers in government, help build a common sense of good management practice in the public service. Recommendations are made for future applications.

Keywords: emotional intelligence, leadership style, senior leaders in government, gender differences.

organisation set the tone for employee morale-their influence often rubs-off on those they lead in their teams both negatively and positively, depending on the leader's leadership style. Naidoo and Xollie (2011) explain that the South African public sector is reeling from the barrage of new initiatives with respect to the government's transformation agenda, and from a plethora of targets that need to be achieved in the public sector.

* N. M. G. Mfikwe, Graduate School of Business \& Government Leadership, North-West University, Mafikeng Campus, South Africa

** T. G. Pelser, PhD, Professor. Graduate School of Business and Leadership, Dean and Head of School. University of KwaZulu-Natal, Private Bag X54001, Durban, South Africa. Email: pelser@ukzn.ac.za 
Unlike few other business concepts, the notion of an emotionally intelligent leader has caught the interest and stirred the imagination of scholars and practitioners alike (Walter et al., 2012). According to Hur et al. (2011) the study of emotions in the context of leadership has become a key topic of interest among organisational behavioural researchers over the past decade. A significant body of research has been built over the past two decades that has found the emotional intelligence abilities to be associated with a range of important work-related behaviours. Particularly significant from a project's perspective have been associations found between emotional intelligence (EI) and leadership, team effectiveness and work group effectiveness (Clarke, 2010).

Goleman (1998) explains that emotional intelligence means managing feelings so that they are expressed appropriately and effectively, enabling people to work together smoothly toward their common goal. Goleman (1998) further argues that women are not 'smarter' than men when it comes to emotional intelligence, nor are men superior to women. An analysis of emotional intelligence in thousands of men and women found that women, on average, are more aware of their emotions, show more empathy, and are more adept interpersonally. Men on the other hand, are more self-confident and optimistic, adapt more easily and handle stress better (Goleman, 1998).

In his most recent study, Goleman (2014) explains that not all emotional partners are equal and that a power dynamic operates in emotional contagion determining which person's brain will more forcefully draw the other into its emotional orbit. Related to the above notion, global research conducted by the Hay Group (2012) shows that successful women leaders often display versatility in management styles. They tend to adapt their style to the demands of the situation and are less inclined to adhere to one particular style. As a result they create better performance-driven climate than their male counterparts which is the essence of Emotional Intelligence (EI) in a management context.

According to Thornton (2014), women currently hold only $26 \%$ of senior management positions in South Africa and $21 \%$ of local businesses have no women at all in senior management positions. This is in stark contrast to emerging countries like Russia and China, where a much higher number of women feature in leadership positions in organisations. The number of women in senior positions in businesses throughout South Africa has decreased by $2 \%$ since 2014 , but has remained fairly fixed between $26 \%$ and $28 \%$. Nonetheless, a total of $34 \%$ of South African businesses employed female human resource directors and the same percentage had female Chief Financial Officers (CFOs) which show an increase of $2 \%$ since 2014 and $7 \%$ since 2013. Despite the drop of women in senior positions since 2014, the leadership quotas remained a clear directive for business and the public sector to allow for equal opportunities for women in the workplace (Thornton, 2014).

\section{PROBLEM STATEMENT}

The presence of women in senior management roles, especially in the South African context, has changed management cultures in most organisations. Leaders in every organisation need high emotional intelligence because they represent the organisation to the public, to those they lead and those they interact with on behalf of the organisation. Most of all, leaders in the organisation, set the tone for employee morale -their influence often rubs-off on those they lead in their teams both negatively and posi- 
tively, depending on the leader's leadership style.

A lack of understanding of whether males or females have a better sense of emotional intelligence and leadership styles to share a vision with their employees may result in poor or weak service delivery output. It could also indirectly affect the equity ratio that South Africa strives to achieve in order to promote equality amongst all its citizens in the workplace. Despite the directive to consider the equity quotas when positions are filled in the civil services, i.e. attaining the 50:50 male and female representation at senior or leadership levels, one of the key challenges of the South African Public Service is to recruit, develop and retain competent leaders and managers.

Senior managers in Government and Public Service managers have an important task of transforming the strategic vision, goals and objectives of government into effective service delivery. Unfortunately, the South African public sector is reeling from the barrage of new initiatives with respect to the government's transformation agenda, and from a plethora of targets that need to be achieved in the public sector. The leadership styles and emotional intelligence of the senior managers of the North West Provincial Government Public Service will contribute to a sense of shared vision of providing a qualitative service to the public and ensuring that the citizens have faith in government systems.

Organisations that want to be a cut above the rest would depend on recruiting the right leaders with the right attitude and leadership style. These leaders would in turn be able to influence, motivate and promote the culture of effective service delivery. They would inculcate a culture of shared responsibility, a sense of ownership and yearning to deliver impeccable services to its public. In the case whereby male and female leadership styles are not the same, this would also serve as motivation to design development opportunities or interventions to assist senior managers to obtain the required or most relevant managerial qualities that could assist the managers to lead their teams and the entire organisation.

\section{RESEARCH AIM AND QUESTIONS}

The main purpose of this study is to measure and analyse the levels of emotional intelligence of male and female senior managers in the South African Government, in order to identify if their emotional intelligence has an influence on their leadership styles and subsequently make specific recommendations for implementing interventions to resolve any discrepancies. This research aims at understanding the leadership styles of males and females in senior positions.

The second purpose is to identify if emotional intelligence has an impact on leadership and vice versa, if leadership has an impact on emotional intelligence. Emotional intelligence is regarded as a leadership competence and thus a high level of emotional intelligence should enable a senior manager to be more efficient and effective in organisational relationship building.

The following research questions were addressed:

1. Does the leadership style of men and women senior leaders have a significant impact on their emotional intelligence?

2. Does emotional intelligence support the type of leadership style that male and female senior leaders display?

3. Does emotional intelligence enable leadership? 
4. Do women senior managers display a higher degree of emotional intelligence than male senior leaders or managers in the South African Government?

\section{LITERATURE REVIEW}

According to Muchinsky (2000), it is now the time for organizational behaviour scientists to acknowledge emotions as a "legitimate domain of scientific inquiry", especially as it leads to awareness in the implicit judgment of significant events, revealing needs, concerns and motives. Chen et al. (1998) as cited in Fatt and Howe (2003) state that approximately 90 percent of successes in leadership positions is attributed to emotional intelligence. Authors such as Littrel and Nkomo (2005) wrote about the gender and race difference in leadership behaviour preferences in South Africa. Booysen (2001) cited in Littrel and Nkomo (2005) examined subculture differences and similarities between South African male and female managers in retail banking and found that South African male managers focused on performance, competition and winning, domination, control, and directive leadership, whereas she found that South African female managers emphasised collaboration, participation, intuition, empowerment, and empathy.

Ozcelik et al. (2008) found that team leaders who facilitated positive working relationships amongst team members created more positive team climates, which resulted in increased team-level performance. Some literature has shown that the various styles of leadership can be attributed to emotional intelligence and gender differences (Gardner \& Stough, 2002; Palmer, et al., 2001). McColl-Kennedy and Anderson (2002), cited in Bass and Riggio (2006) found that transformational leadership behaviours, such as inspirational motivation and individual consideration, helped employees cope with frustrating work events and assisted them to feel more optimistic at work. This in turn led to increased individual-level sales performance.

Goleman (1998) explains that emotional intelligence means managing feelings so that they are expressed appropriately and effectively, enabling people to work together smoothly toward their common goal. Goleman (1998) further argues that women are not 'smarter' than men when it comes to emotional intelligence, nor are men superior to women. In a later study, Dulewicz and Higgs (2000) argue that emotional intelligence is about knowing what you are feeling and being able to deal with those feelings without having them swamp you. It is being able to motivate yourself to get the jobs done, being creative and performing at your peak. Also, it is to sense what others are feeling, and dealing with relationships effectively. In this study, the concept of emotional intelligence is applied on the basis of the conceptualisation of Schutte et al. (1998) which is that higher emotional intelligence is associated with a higher positive mood state and greater state of self-esteem.

In relation to higher emotional intelligence being associated with a higher positive mood state and self-esteem, Murray (2006) on the other hand, found that women score higher than men on measures of empathy and social responsibility. On the other hand, men outperform women on measures of stress tolerance and self-confidence. Murray (2006) concludes in her study that women and men are equally intelligent emotionally, but their strength lies in different areas. The areas where an inadequacy exists in women may be cultivated through techniques such as stress management whereas men can learn the importance of listening to co-work- 
ers and customers, sensing and interpreting their moods and winning their trust. This suggests that emotional intelligence can be facilitated through training in both men and women to optimise functioning in the workplace. Gardner and Stough (2002) support this and indicate that emotional intelligence testing may improve an organisation's ability to predict who will be an effective leader, who will manage a productive group and who will be satisfied in their own job, who will not avoid responsibility, but also who will be absent when needed.

According to Goleman (2014), leadership boils down to a series of social exchanges in which the leader can drive the other person's emotions into a better or worse state. Callousness from a boss not only heightens the risk of losing good people but it also torpedoes cognitive efficiency. Goleman (2014) further argues that a socially intelligent leader helps people contain and recover from their emotional distress if only from a business perspective. Thus, a leader would do well to read with empathy rather than indifference, and to act on it.

As more women begin occupying positions of leadership, questions as to whether they lead in a different manner from men and whether women or men are more effective as leaders, have garnered greater attention (Quader, 2011). In a comparative study in which Petrides and Furnham (2006) measured emotional intelligence females scored higher than males in social skills. In a self-estimate of emotional intelligence men scored higher on certain factors compared to women (Petrides and Furnham, 2006) .Based on this research, it was hypothesised that those who rated themselves high in emotional intelligence would have better leadership abilities. Furthermore, it was hypothesised that females would score higher in EI and leadership than males, which sug- gests that females take a more relationshiporiented style of leadership.

TheTurnkett Leadership Group (2002) found that $51 \%$ of respondents agreed or strongly agreed that women are more predisposed to be developed as talent in the workplace. $47 \%$ agreed or strongly agreed that women's teambuilding skills are more effective than those of their male counterparts. The lowest scores were for women being more effective than men in achieving results where only $20 \%$ agreed or strongly agreed. They concluded that the responses could be grouped into three categories: 1) emotional intelligence and empathy, 2) ability to multitask, and 3) ability to communicate and build consensus.

The reviewed literature suggests that female senior managers have better emotional intelligence than their male counterparts in the workplace and that women-led teams are more psychologically or emotionally well and productive compared to male-led teams. This study will explore this assertion further.

The literature review provided various theoretical perspectives and conceptual knowledge on emotional intelligence and leadership styles of senior managers. This section highlighted that teams and personnel are important assets in achieving organisation's goals. It does however take Emotionally Intelligent and astute leaders to promote a particular vision to its followers. Employees need to be managed in such a way that they not only buy-in to the same vision as the leaders, but carry it forth with pride and zeal.

\section{RESEARCH METHODOLOGY}

A cross sectional design survey was used to answer the research questions. Participants $(n=85)$ were purposively selected from a relatively small group of senior managers 
in the South African Government. All attempts were made to select an equal number of males and females. The participants ranged from Directors, Chief Directors, Deputy Directors General and two Superintendent Generals and in terms of education the respondents held Doctoral to Bachelors' degrees (see Table 1).
The Leadership Style Survey [LSS] (Clark, 1998 ) is a 30 item measure which contains statements about leadership style beliefs. It was used in this study to distinguish the various leadership styles. Clark (1998) identifies three leadership styles: authoritarian, participative, and delegation. The Generalised Self- Efficacy Scale [GSES] (Schwarzer \&

Table 1: Characteristics of Participants

\begin{tabular}{|l|l|c|c|}
\hline Variable & & Frequency & $\mathbf{\%}$ \\
\hline Gender & Male & 48 & 56.47 \\
\hline & Female & 37 & 43.53 \\
\hline & & & \\
\hline Position & Director & 52 & 61.18 \\
\hline & Chief Director & 23 & 27.06 \\
\hline & DDG & 8 & 9.41 \\
\hline & SG & 2 & 2.35 \\
\hline & & & \\
\hline Years Position & 0 to 2 & 20 & 23.53 \\
\hline & 2 to 5 & 24 & 28.24 \\
\hline & 5 to 7 & 16 & 18.82 \\
\hline & $8+$ & 20 & 23.53 \\
\hline Education & & & \\
\hline & PhD & 13 & 15.29 \\
\hline & Masters & 30 & 35.29 \\
\hline & Honours & 21 & 24.71 \\
\hline & Bachelor's degree & 18 & 21.18 \\
\hline & Diploma & 3 & 3.53 \\
\hline
\end{tabular}

The demographic questionnaire used a self-report survey instrument to obtain demographic information on the gender, position held by participants, number of years they have held a specific position or designation, and their levels of education. The Self-Report Emotional Intelligence Scale [SREIS] (Schutte et al., 1998) was employed. This is a 33 item self-report measure of emotional intelligence. The SREIS has been designed to map onto the Salovey and Mayer (1990) model of EI. Items of the test relate to the three aspects of emotional intelligence: appraisal and expression of emotion; regulation of emotion and utilisation of emotion.
Jerusalem, 1995) is a 10 item scale created to assess a general sense of perceived selfefficacy with the aim in mind to predict coping with daily hassles as well as adaptation after experiencing all kinds of stressful life events. The Constructive Thinking Inventory [CTI] (Epstein and Meier, 1989) assessed the constructive and destructive beliefs and thinking patterns of the respondents. This scale measures the efficacy of the experiential system whilst the intelligence tests measure the efficacy of the intellectual system.

The Cronbach Alpha resulted in a coefficient of 0.876 for all the scales. This reflects 
a high reliability of the 119 items used for the questionnaires. For random samples, the statistical significance of such relationships are determined with Chi-square tests, but actually one wants to know whether the relationship is large enough to be important. What is significant to this study is that the effect size is again independent of sample size. The following guidelines were used for the interpretation in the current case:

(a) small effect: $w=0.1$

(b) medium effect: $w=0.3$

(c) large effect: $w=0.5$

(d) A relationship with $w \geq 0.5$ is considered as practically significant.

\section{RESULTS}

This section discusses the key findings according to the data interpretation. The discussion is based on the results obtained on each of the research questions:
Quader (2011) is of the opinion that, even if gender differences between male and female leadership did exist, both genders are necessary in running a business. Certain masculine traits, such as the ability to focus and take action, are essential to a business success, so are the feminine qualities of relationship building, emotional mentoring, communication, multitasking, intuition and compassion which offer business a very different perspective from the more commonly recognized masculine traits (Quader, 2011).

Question 2: Does emotional intelligence support the type of leadership style of the male and female senior leaders?

The chi-square test in Table 2 shows a statistically significant difference at the $5 \%$ level of significance. Gender plays a vital role in the leadership style and only two statements were influenced by gender. In a related study, Khalili (2012) discovered that women scored higher than men on empathy and social responsibility, while men surpassed women on stress tolerance and self-

Table 2: Chi Square Test

\begin{tabular}{|l|c|c|}
\hline \multicolumn{1}{|c|}{ Statements } & Chi Square & P-value \\
\hline $\begin{array}{l}\text { I do not consider suggestions made by my employees as I do } \\
\text { not have the time for them. }\end{array}$ & 9.635 & 0.047 \\
\hline Each individual is responsible for defining their job. & 9.767 & 0.045 \\
\hline
\end{tabular}

Question 1: Does the leadership style of men and women senior leaders have a significant impact on their emotional intelligence?

None of the statements relating to emotional intelligence showed any statistically significant difference when crossed with gender at the $5 \%$ level of significance. It clearly indicates that leadership style of men and women senior leaders has no significant impact on their emotional intelligence. confidence. His findings suggested women and men are equally Emotionally Intelligent, but they are different in these spheres. In the same breath, Northouse (2013) cautions that the incongruity between the female gender role and the leadership role leads to prejudice against female leaders, who are evaluated and perceived more negatively than their male counterparts. 


\section{Journal of Contemporary Management Issues}

Question 3: Does emotional intelligence enable leadership?

The majority $(90 \%)$ of the respondents indicated that they don't know when to speak about their personal problems to others. The similarly large share of respondents $(91 \%)$ are of the view that when they are faced with obstacles, they remember times they faced similar obstacles and overcame them, that they expect that they will do well on most things they try, that other people find it easy to confide in them, that they find it hard to understand the non-verbal messages of other people. A non-conclusive majority $(53 \%)$ did not concur that some of the major events of their life have led them to re-evaluate what is important and not important. A good proportion $(73 \%)$ concur that when their mood changes, they see new possibilities, that emotions are one of the things that make their life worth living, that they are aware of their emotions as they experience them, that they expect good things to happen, that they like to share their emotions with others, and that when they experience a positive emotion, they know how to make it last. It was also evident from the data that a majority $(79 \%)$ of the respondents agreed that they arrange events that other enjoy, that they seek out activities that make them happy, that they are aware of the non-verbal messages they sent to others and lastly that they present themselves in a way that makes a good impression on others. Accordingly, the majority $(86 \%)$ of the respondents agreed that when they are in a positive mood, solving problems is easy for them, that by looking at other people's facial expressions they recognise the emotions they are experiencing, that they know why their emotions change, that when they are in a positive mood they are able to come up with new ideas, that they have control over their emotions, and that they easily recognize their emotions as they experience them.

The analysis highlighted the fact that the vast majority $(85 \%)$ of the respondents agreed that they motivate themselves by imagining a good outcome to tasks they take on, that they complement others when they have done something well, that they are aware of the non-verbal messages other people send, that when another person tells them about an important event in his or her life they almost feel as though they have experienced this event themselves, that when they

Table 3: Chi Square Test

\begin{tabular}{|l|c|c|}
\hline \multicolumn{1}{|c|}{ Statements } & Chi Square & P-value \\
\hline Female Leadership vs I like to share my emotions with others & 12.872 & 0.012 \\
\hline $\begin{array}{l}\text { Female Leadership vs When I feel a change in emotions I tend to } \\
\text { come up with new ideas }\end{array}$ & 18.961 & 0.004 \\
\hline $\begin{array}{l}\text { Female Leadership vs When I am faced with a challenge I give } \\
\text { up because I believe I will fail }\end{array}$ & 23.108 & 0.003 \\
\hline $\begin{array}{l}\text { Female Leadership vs I can tell how people are feeling by } \\
\text { listening to the tone of their voice }\end{array}$ & 12.915 & 0.044 \\
\hline $\begin{array}{l}\text { Male Leadership vs Emotions are one of the things that make } \\
\text { my life worth living }\end{array}$ & 25.410 & 0.013 \\
\hline $\begin{array}{l}\text { Male Leadership vs I am aware of the non-verbal messages other } \\
\text { people send }\end{array}$ & 10.485 & 0.015 \\
\hline
\end{tabular}


feel a change in emotions they tend to come up with new ideas, that when they are faced with a challenge they give up because they believe they will fail. A significant proportion $(93 \%)$ of the respondents are opposed to the fact that they know what other people are feeling just by looking at them, and were unsure that they help other people feel better when they are down. The majority of the respondents (97\%) agreed that they use a good mood to help themselves keep trying in the face of obstacles, that they can tell how people are feeling by listening to the tone of their voice and lastly that it is difficult for them to understand why people feel the way they do.

The above information deduced from the data demonstrates that there is a link if not a clear correlation between leadership and emotional intelligence. It is apparent that emotional intelligence factors directly affect leadership decisions and a positive environment. Baron (2014) claims that every interaction is an opportunity to engage, empower and inspire or distance, disempower and disenfranchise those around you and thus leaders must have the emotional intelligence to understand that every interaction sits on the fulcrum between two possibilities: nurturing relationships, thus eliminating the obstructions to progress, reinforcing trust and loyalty or creating obstacles and eating away at whatever trust has been established.

Question 4: Do women senior managers have better emotional intelligence than male senior leaders or managers in the South African Government?

The chi-square test in Table 3 shows a statistically significant difference at the 5\% level of significance. Gender plays a vital role in the leadership role and some emotional intelligence items on the Emotional Intelligence Scale (EIS); (I like to share my emotions with others; when I feel a change in emotions, I tend to come up with new ideas; When I am faced with a challenge, I give up because I believe I will fail; I can tell how people are feeling by listening to the tone of their voice; emotions are one of the things that make my life worth living and I am aware of the non-verbal messages other people send).

In a similar study, Coetzee and Schaap (2005) conclude that the level of a leader's emotional intelligence determines whether or not such a leader is able to influence behaviour and take individual developments into consideration through the intellectual stimulating of followers. Coetzee and Schaap's (2005) analysis confirms that an Emotionally Intelligent leader is able to instil trust and commitment and motivate followers to exert extra effort, which in turn creates a feeling of satisfaction once the set goals are reached.

\section{RECOMMENDATIONS AND CONCLUSION}

Although the previous literature showed that women leaders have better emotional intelligence as opposed to their male counterparts, and possible differences in leadership style are related to each other, the findings of this study did not show significant differences. Therefore, leaders with high emotional intelligence are bound to understand that whatever gender, their message, and communiqué they transmit, may spark positive or negative reactions from the employees they manage, thus they have to be calculative and deliberate in the messages and communication they transmit, for the overall benefit of the organisation and those they lead.

Senior managers in government are expected to have some of the following key 
competencies: change management, knowledge management, strategic capability and leadership, programme and project management, service delivery innovation, problem solving and analysis, people management and empowerment, client orientation and customer focus, communication, honesty and integrity. Recruitment procedure for these senior managers should involve competency assessments.

The aim of this study was to compare leadership styles of female and male senior leaders in government in relation to their emotional intelligence. The results of the study indicated that there were no differences in the leadership styles of male and female managers. Secondly, the results also showed that there were no differences in the levels of emotional intelligence of male and female managers. However, emotional intelligence and leadership are two important correlates of which leadership provides the context in which emotional intelligence operates. Thus, it is critical to promote these two qualities among senior leadership if the

\section{References}

1. Baron, D. (2014). What's Your Emotional Footprint? https://www.linkedin.com/ pulse/20141031230420-2877302-whats-your-emotional-footprint[Date of access 30/10/2016].

2. Bass, B.M. \& Riggio, R. (2006). Transformational Leadership. $2^{\text {nd }}$ ed. Mahwah, NJ: Lawrence Erlbaum.

3. Clark,D. (2002). Leadership Style Survey. http://www.nwlink.com/ doncclark/ leader/ survstyl.html [Date of access 30/10/2016].

4. Clarke, N. (2010). Emotional Intelligence and Its Relationship to Transformational Leadership and Key Project civil service has to promote a shared vision and provide equitable service to the public.

It is also very clear from the data that emotional intelligence is an enabler of leadership. Emotional intelligence factors directly affect leadership decisions and a positive environment. Significant change in organisational culture, the employment equity directive of including more women in leadership in South African organisations and better understanding of leadership qualities and emotional intelligence of both women and men, may assist in appreciating the need for both genders in the workplace.

Lastly, gender plays a vital role in the leadership role and some emotional intelligence scales as confirmed above. It would be to the added advantage of South African organisations, especially the public sector, to strive towards the much advocated 50:50 employment equity directive of women and men in the workplace. This is specifically the case if South Africa is to live up to best practices of developing countries and maintain its competitive edge.

Manager Competences. Project Management Journal, 41(2), 5-20.

5. Coetzee, C. \& Schaap, P. (2005). The Relationship between Leadership Behavior, Outcomes of Leadership and Emotional Intelligence. SA Journal of Industrial Psychology, 31(3),31-38.

6. Dulewicz, V. \& Higgs, M.J. (2000). Emotional Intelligence: A Review and Evaluation Study. Journal of Managerial Psychology, 15(4), 341-368.

7. Epstein, S. \& Meier, P. (1989). Constructive Thinking: A Broad Coping Variable with Specific Components. Journal of Personality and Social Psychology, 57(2), 332-350. 
8. Fatt,J.P.T. \& Howe, I.C.K. (2003).Emotional Intelligence of Foreign and Local University Students in Singapore: Implications for Managers. Journal of Business and Psychology, 17(3), 345367.

9. Gardner, L. \& Stough, C. (2002).Examining the Relationship between Leadership and Emotional Intelligence in Senior Level Managers. Leadership \& Organisation Development Journal, 23(2), 68-78.

10. Goleman,D. (1998). Working with Emotional Intelligence. New York: Bantam Books.

11. Goleman, D. (2014). What Makes a Leader: Why Emotional Intelligence Matters. Florence, MA: More Than Sound.

12. Hay Group. (2012). Learning from their success: A study into women executives. http://www.haygroup.com/downloads/ au/Womens_\%20research_whitepaper. pdf [Date of access 30/10/2016].

13. Hur, Y., van den Berg, P. T. \& Wilderom, C. P. M. (2011). Transformational leadership as a mediator between emotional intelligence and team outcomes. The Leadership Quarterly, 22(4), 591-603.

14. Schwarzer, R. \& Jerusalem, M. (1995). Generalized Self-Efficacy Scale. In J. Weinman, S. Wright, \& M. Johnston, Measures in Health Psychology: A User's Portfolio. Causal and Control Beliefs. Windsor, UK: NFER-Nelson.

15. Khalili, A. (2012). The Role of Emotional Intelligence in the Workplace: A Literature Review. International Journal of Management, 29(3), 355-370.

16. Littrel, R.F. \& Nkomo, S.M. (2005). Gender \& Race Differences in Leader Behavior Preferences in South Africa. Women in Management Review, 20(8), 562-580
17. Muchinsky, P.M. (2000). Emotions in the Workplace: The Neglect of Organisational Behavior. Journal of Organisational Behavior, 21(7), 801-805.

18. Naidoo, G. \& Xollie, T. (2011). The Critical Need for an Integrated Leadership Approach toImprove Service Delivery by the South African Public Service. Journal of US-China PublicAdministration, 8(1), 1-15.

19. Northouse, P.G. (2013). Leadership: Theory and Practice. 6th ed. Los Angeles: SAGE Publications Inc.

20. Ozcelik, H., Langton, N. \& Aldrich, H. (2008). Doing Well and Doing Good: The Relationship between Leadership Practices that Facilitate a Positive Emotional Climate and Organisational Performance. Journal of Managerial Psychology, 23(2), 186-203.

21. Palmer, B. Walls, M. Burgess, Z. \& Stough, C.(2001). Emotional Intelligence and Effective Leadership. Leadership \& Organisation Development Journal, 22(1), 5-10.

22. Quader, M.S. (2011). Leadership Style and Emotional Intelligence: A Gender Comparison. Annamalia International Journal of Business Studies \& Research, 1(1), 1-23.

23. Salovey, P. \& Mayer, J. D. (1990). Emotional Intelligence. Imagination, Cognition, and Personality, 9(1), 185211.

24. Schutte, N. S., Malouff, J. M., Hall, L. E., Haggerty, D. J., Cooper, J. T. \& Golden, C. J. (1998). Development and Validation of a Measure of Emotional Intelligence. Personality and Individual Differences, 25(1), 167-177.

25. Thornton, G. (2014). Still Only a Quarter of Senior Business Positions Filled by Women in SA.http://www.gt.co.za/ news/2014/03/still-only-a-quarter-of- 
senior-business-positions-filled-bywomen-in-sa-grant-thornton-survey/ [Date of access: 30/10/2016]. tial: Toward an Evidence-Based Management of Emotional Intelligence. Organizational Dynamics, 41(3), 212-219.

26. Walter, F., Humphrey, R. H. \& Cole, M.

S. (2012). Unleashing leadership poten-

\section{ZNAČAJ EMOCIONALNE INTELIGENCIJE I STILOVA VOĐENJA VIŠE POZICIONIRANIH VOĐA U JUŽNOAFRIČKOJ VLADI}

\section{Sažetak}

Značajan je broj istraživanja u posljednja dva desetljeća utvrdio da je sposobnost emocionalne inteligencije povezana $s$ nizom značajnih oblika radnog ponašanja. Cilj ovog rada je utvrditi razlike među spolovima $i$ značaj emocionalne inteligencije te stilova vođenja više pozicioniranih vođa $u$ vladi Južnoafričke Republike. Za ovu je svrhu izabran uzorak, koji se sastojao od 85 više pozicioniranih menadžera, iz različitih vladinih odjela u Južnoj Africi. Rezultati istraživanja pokazuju povezanost emocionalne inteligencije i stilova vođenja. Međutim, pritom nisu utvrđene značajne razlike $u$ stilovima vođenja $i$ emocionalnoj inteligenciji između muških $i$ ženskih sudionika/ica istraživanja. Razlog navedenog može se pronaći u činjenici da ključni menadžerski kriteriji i standardi, korišteni za procjenu učinka viših menadžera $u$ vladinoj službi pomažu u razvoju općih načela dobre menadžerske službe u javnom sektoru. U radu se daju i preporuke za daljnju primjenu razmatrane problematike.

Ključne riječi: emocionalna inteligencija; stil vođenja; više pozicionirani menadžeri $u$ javnoj službi; razlike među spolovima. 